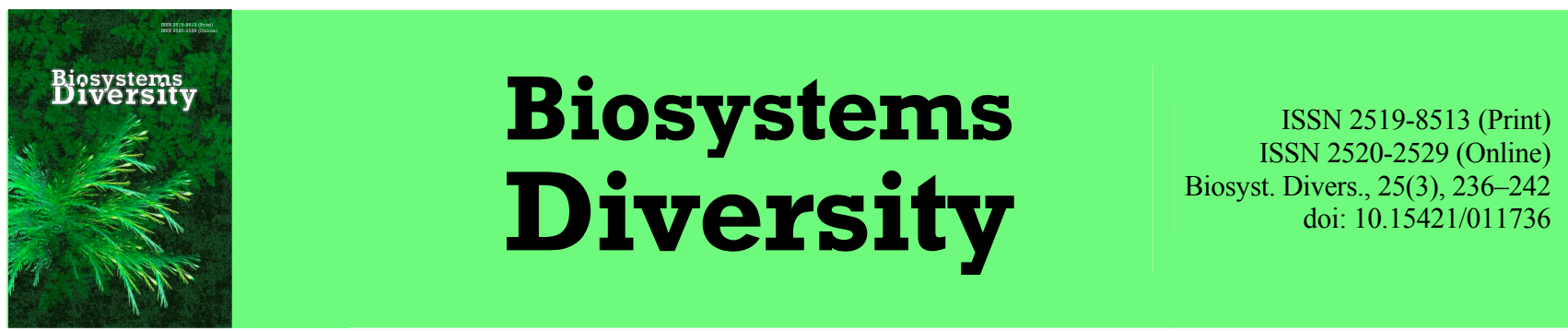

\title{
The influence of synthetic food additives and surfactants on the body weight of larvae of Tenebrio molitor (Coleoptera, Tenebrionidae)
}

\author{
V. O. Martynov, V. V. Brygadyrenko \\ Oles Honchar Dnipro National University, Dnipro, Ukraine
}

Article info

Received 19.06.2017

Received in revised form 07.08.2017

Accepted 11.08.2017

Oles Honchar Dnipro National University

Gagarin Ave., 72,

Dnipro, 49010, Ukraine.

Tel. +38-050-939-07-88.

E-mail:

martinov123456789@gmail.com

brigad@ua.fm

\begin{abstract}
Martynov, V. O., \& Brygadyrenko, V. V. (2017). The influence of synthetic food additives and surfactants on the body weight of larvae of Tenebrio molitor (Coleoptera, Tenebrionidae). Biosystems Diversity, 25(3), 236-242. doi:10.15421/011736
\end{abstract}

The broad spectrum of negative effects of food additives and surfactants on living organisms and the environment in general indicate a necessity of a detailed study on this issue. The aim of this article is to evaluate the impact of food additives and surfactants in a concentration of $350 \mathrm{mg} / \mathrm{kg}$ of fodder on the body weight of third age Tenebrio molitor Linnaeus, 1758 (Coleoptera, Tenebrionidae) larvae. A significant change in the body weight of $T$. molitor larvae was observed when they consumed a diet containing $350 \mathrm{mg} / \mathrm{kg}$ of sodium glutamate, sodium cyclamate and sodium benzoate. We observed a tendency towards increase in body weight after addition of the food colouring Allura Red, saccharin, benzoic acid, betaine, emulsifying wax, AOS and SLES, and also we observed a decrease in body weight after addition of Tartrazine and Indigo Carmine in the same concentration. Out of the 18 tested food additives, 3 significantly stimulated an increase in the body weight of third age T. molitor larvae, and 3 manifested the same effect at the level of tendency (stimulated an increase in mass on average by $43-58 \%$ over the 14-day experiment), and 2 caused decrease in the body weight of larvae. Also, the 4 studied surfactants manifested a tendency towards increase in the body weight of T. molitor. This study on the impact of food additives and surfactants on organisms of insects is of great significance for protecting rare species of insects.

Keywords: source materials; taste modifiers; food colourings; sweeteners; body weight; healthy diet

\section{Introduction}

The use of food additives in developed countries continues to increase (Bobyliov et al., 2014). Organic molecules used as synthetic food additives are heterogenous to living organisms. In humans or animal organisms they may cause various diseases (Ashida et al., 2000; Boyko and Brygadyrenko, 2017). Food additives enter the environment in different ways and become the food of litter and soil saprophages. A considerable amount of these substances which were unused in production are deposited on dumping grounds for solid municipal waste; the substances used in human food, after passing through the intestines, enter the municipal sewage treatment facilities. Therefore, the substances one way or another become included in the food of terrestrial and aquatic saprophage animals (Kroes and Kozianowski, 2002). On the whole, the impact of food additives on the organisms of insects remains virtually unstudied (Bobyliov et al., 2014; Boyko and Brygadyrenko, 2017).

Food additives are classified into colourings $\left(\mathrm{E}_{100}-\mathrm{E}_{199}\right)$, preservatives $\left(\mathrm{E}_{200}-\mathrm{E}_{299}\right)$, antioxidants $\left(\mathrm{E}_{300}-\mathrm{E}_{399}\right)$, stabilizers $\left(\mathrm{E}_{400}-\mathrm{E}_{499}\right)$, emulsifiers $\left(\mathrm{E}_{500}-\mathrm{E}_{599}\right)$, modifiers of taste and flavor $\left(\mathrm{E}_{600}-\mathrm{E}_{699}\right)$, antiflamings $\left(\mathrm{E}_{900}-\mathrm{E}_{999}\right)$

Preservatives are used for preventing decomposition and bacterial infestation of products. In the intestine of insects these substances are assumed to selectively eliminate certain species of microorganisms, thus causing intense breeding of other species of microorganisms (including those pathogenic for insects). Many preservatives have a broad negative impact on organisms of animals and humans (migraines, depression, irritable bowel syndrome, etc) (Moutinho et al., 2007). For example, consumption of monosodium glutamate causes increase in the body weight of animals as a result of increase in the amount of the consumed product. Also, decrease in the mass of kidneys, pancreas, spleen, and a hepatoxic effect caused by this substance have been determined
(Alirezaei et al., 2011). The food industry uses colourings for improving the appearance of products, (Hansen et al., 1963; Maekawa et al., 1987; Gao et al., 2011). Unlike natural colourings, synthetic colourings are widely used due to their intense colouring properties, homogeneity, stability and low cost. Many synthetic colourings have a toxic impact following their long term consumption, causing digestive problems, allergic reactions, causing damage to the brain, kidneys, liver, and resulting in anomalies in development of progeny (Mannell et al., 1962; Ashida et al., 2000; Kroes and Kozianowski, 2002; Moutinho et al., 2007).

The most common environmental pollutants also include surfactants (Fitzhugh and Nelson, 1948). In the environment, they can be quickly destroyed by bacteria and fungi, or, on the contrary, can accumulate in the organisms of animals and in high concentrations (Nair, 1998). Most surfactants have a broad range of negative impact on the organisms of humans and animals. They take part in the rearrangement of other groups of pollutants (heavy metals, petrochemicals, pesticides, etc.), slow down the decomposition of carcinogens, inhibit the consumption of oxygen, etc. The sources of surfactants include detergents, the textile and chemical industries, oil production, agriculture, and public utilities.

Darkling beetles are usually saprophages or phytophages (Medvedev, 1968; Brygadyrenko and Nazimov, 2014, 2015; Nazimov and Brygadyrenko, 2013), and are able to digest many types of food, including food contaminated with additives. Most species of this family have adapted to life in conditions of insufficient moisture and feed on dry food with minimum content of moisture (Chen et al., 2004). The sheer abundance of many Tenebrionidae species, the slow development of their larvae, their ability to accumulate toxins from food in their body, make them convenient objects for ecotoxicological studies.

The broad spectrum of negative impacts of food additives and surfactants on living organisms and the environment in general, 
indicates the necessity of scientific studies on the question. The objective of this research was to evaluate the impact of food additives and surfactants on the body weight of Tenebrio molitor Linnaeus, 1758 (Coleoptera, Tenebrionidae) larvae.

\section{Materials and methods}

The experiment used third age T. molitor larvae. Before the experiment, larvae were kept in a common vessel with standard diet for their maintenance. The experiment was conducted in plastic cups of 0.21 capacity with $37.5 \pm 0.21 \mathrm{~g}$ of dry rolled oats in each cup (the accuracy of weighing the food and larvae equals $0.1 \mathrm{mg}$ ). Using a pipette, the substrate was moistened with aqueous solutions of the studied substances (the accuracy of measuring the volume of the solution equals $0.05 \mathrm{ml}$ ). As a result, the concentration of the substance in the food substrate equaled $350 \mathrm{mg} / \mathrm{kg}$ of fodder (Table 1-3). For the control group of beetles, the rolled oats were moistened with $3.75 \mathrm{ml}$ of distilled water per $37.5 \mathrm{~g}$ of fodder.

Table 1

Food colourings used in the experiment

$\begin{aligned} & \text { The name } \\ & \text { of the } \\ & \text { substance }\end{aligned}$
$\begin{aligned} & \text { Sunset Chemical formula } \\ & \text { Yellow, }\end{aligned}$

The objective of the experiment was to compare the actions of the different food additives in equivalent concentrations and determining the variability of the body weight of $T$. molitor larvae in different variants of the experiment. There is no data on average lethal doses of the studied substances for insects. An experiment on the toxicity of food colourings for rats El-Wahab and Moram (2013) used Carmoisine in the concentration of $70 \mathrm{mg} / \mathrm{kg}$ of fodder. In our experiment the concentration of substances $(350 \mathrm{mg} / \mathrm{kg}$ ) corresponded to a fivefold dose of Carmoisine for rats, which was observed to have a toxic effect. Apart from the food additives, the experiment analyzed addition of surfactants to the diet; some of them are considered relatively safe chemical compounds.

After adding the solutions, the substrate was dried and uniformly mixed for uniform distribution of the active substance through the whole mass of fodder and prevention of mould. In each variant, the experiment was conducted in 8 cups on 8 individuals of third age T. molitor larvae (one in each cup). Before and after the 14-day expe- riment, all individuals were weighed. In the laboratory, we did our best to achieve constant temperature $\left(+19 \ldots+20^{\circ} \mathrm{C}\right)$, illumination and air moisture. The cups with larvae were randomly placed on laboratory tables out of direct reach of sunrays.

Table 2

Food additives of different classes, used in the experiment

\begin{tabular}{|c|c|c|c|c|}
\hline $\begin{array}{c}\text { The name } \\
\text { of the substance }\end{array}$ & $\begin{array}{c}\text { Chemical } \\
\text { formula }\end{array}$ & Structural formula & Properties & $\begin{array}{c}\text { Usage in food } \\
\text { industry }\end{array}$ \\
\hline $\begin{array}{l}\text { Saccharin, } \\
\mathrm{E}_{954}\end{array}$ & $\mathrm{C}_{7} \mathrm{H}_{5} \mathrm{NO}_{3} \mathrm{~S}$ & & $\begin{array}{l}\text { white crystalline } \\
\text { powder with } \\
\text { sweet and } \\
\text { metallic taste }\end{array}$ & sweetener \\
\hline $\begin{array}{l}\text { Cyclamic acid, } \\
\mathrm{E}_{952}\end{array}$ & $\mathrm{C}_{6} \mathrm{H}_{13} \mathrm{NO}_{3} \mathrm{~S}$ & & $\begin{array}{l}\text { white crystalline } \\
\text { powder with } \\
\text { sweet taste }\end{array}$ & sweetener \\
\hline $\begin{array}{l}\text { Monosodium } \\
\text { glutamate, } \\
\mathrm{E}_{621}\end{array}$ & $\mathrm{C}_{5} \mathrm{H}_{8} \mathrm{NaNO}_{4}$ & & $\begin{array}{l}\text { white crystalline } \\
\text { powder with } \\
\text { distinctive taste }\end{array}$ & $\begin{array}{l}\text { taste and fla- } \\
\text { vour modifier, } \\
\text { salt substitute }\end{array}$ \\
\hline $\begin{array}{l}\text { Benzoic acid, } \\
\mathrm{E}_{210}\end{array}$ & $\mathrm{C}_{7} \mathrm{H}_{6} \mathrm{O}_{2}$ & & $\begin{array}{l}\text { white crystalline } \\
\text { powder with } \\
\text { distinctive } \\
\text { flavour }\end{array}$ & vative \\
\hline $\begin{array}{l}\text { Sodium } \\
\text { benzoate, } \\
E_{211}\end{array}$ & $\mathrm{C}_{7} \mathrm{H}_{5} \mathrm{O}_{2} \mathrm{Na}$ & & $\begin{array}{l}\text { white crystalline } \\
\text { powder with no } \\
\text { flavour }\end{array}$ & preservative \\
\hline $\begin{array}{l}\text { 4-Aminobenzoic } \\
\text { acid }\end{array}$ & $\mathrm{C}_{7} \mathrm{H}_{7} \mathrm{NO}_{2}$ & & $\begin{array}{c}\text { white crystalline } \\
\text { powder }\end{array}$ & $\begin{array}{l}\text { vitamin } \\
\text { additive }\end{array}$ \\
\hline
\end{tabular}

Table 3

Surfactants used in the experiment

$\begin{gathered}\text { The name } \\ \text { of the } \\ \text { substance }\end{gathered}$
$\begin{gathered}\text { Olefin } \\ \text { Alpha- } \\ \text { (AOS) }\end{gathered}$

Average initial body weight of $T$. molitor larvae equaled $41.4 \pm$ $3.7 \mathrm{mg}(\mathrm{x} \pm \mathrm{SD}, \mathrm{n}=134), 14$ days after the beginning of the experiment the mass of the larvae increased to $59.4 \pm 7.6 \mathrm{mg}$.

The statistical analysis of the results was conducted in Statistica 8.0 (StatSoft Inc., USA). The differences between the selections were found using one-way ANOVA and considered significant at $\mathrm{P}<0.05$.

\section{Results}

During the experiment, we did not observe death or moulting of the larvae. The changes in the body weight of the T. molitor larvae in the 14-day laboratory experiment on adding different substances to the food substrates are presented in Figures 1, 2 and 3. Following the addition of food additives to the fodder, the most clearly manifested differences were observed in the groups fed with substrate containing monosodium glutamate $(\mathrm{P}<0.01)$. A significant increase in body weight was also observed after addition of sodium cyclamate $(\mathrm{P}<0.05)$ and sodium benzoate $(\mathrm{P}<0.05)$.

An insignificant impact on the body weight of $T$. molitor larvae was caused by Allura Red, Tartrazine, Indigo Carmine, saccharin, benzoic acid, AOS, betaine, emulsifying wax and SLES $(\mathrm{P}>0.05)$. 


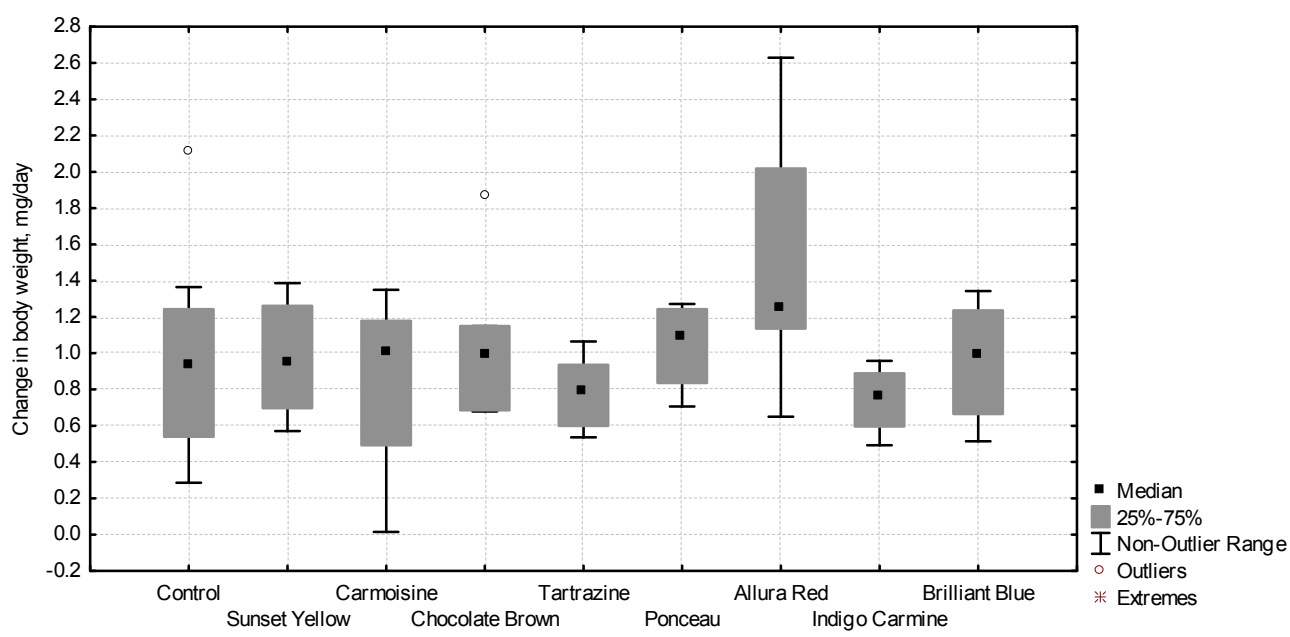

Fig. 1. Change in the body weight of $T$. molitor larvae over the 14-day experiment involving feeding with the substrate saturated with food colourings $(\mathrm{n}=8)$

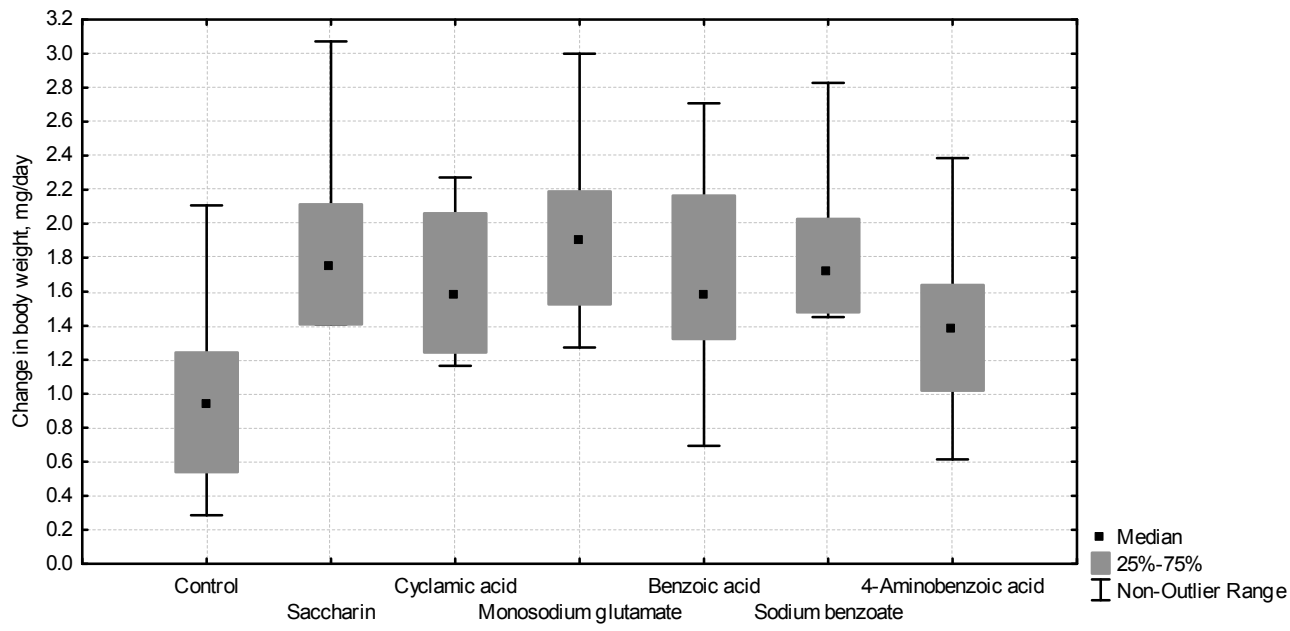

Fig. 2. Change in the body weight of $T$. molitor larvae over the 14-day experiment involving feeding with the substrate saturated with food additives $(n=8)$

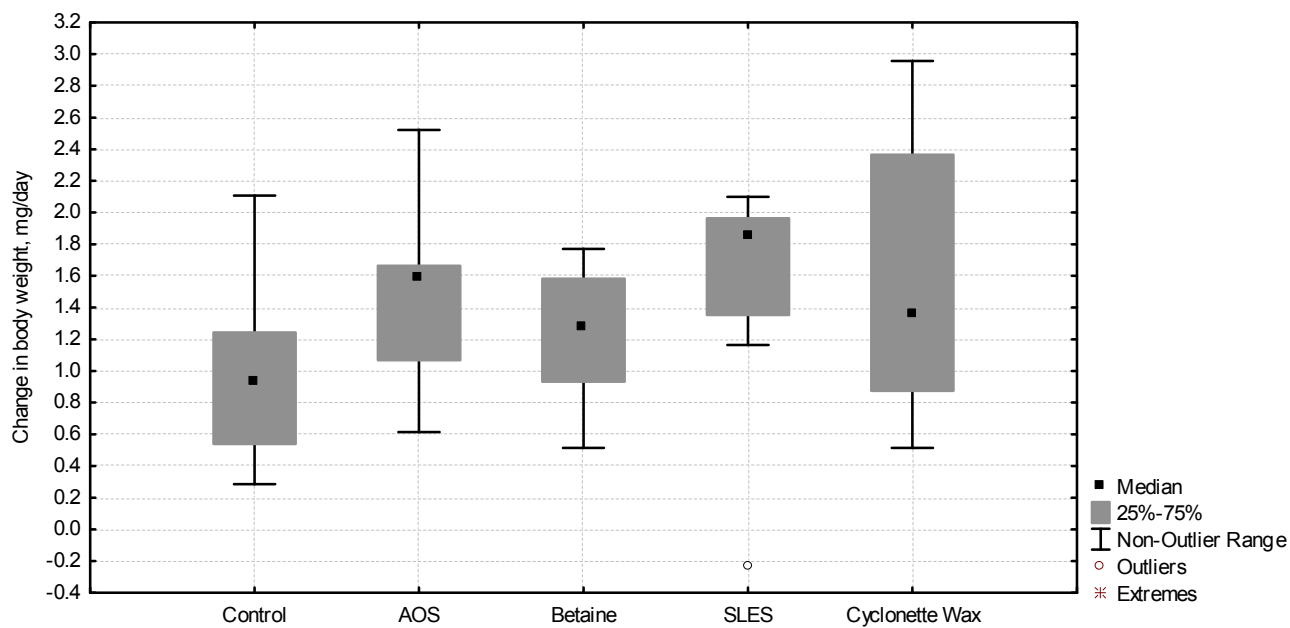

Fig. 3. Change in the body weight of $T$. molitor larvae over the 14-day experiment involving feeding with the substrate saturated with surfactants $(n=8)$

\section{Discussion}

The results indicate that the concentrations included in the diet of T. molitor larvae caused increase in the body weight rather than decrease. Such effect can be explained by disorders in the insects' meta- bolism and increased consumption of food. Decrease in the body weight can be caused by binding of the food additives to the surface of bacterial cells in the insects' intestine, which leads to reduction in the population of bacteria and inhibition of the consumption capacity of the intestine. 
There are few studies on the impact of food additives on the variability of the mass and other characteristics of insects. Nevertheless, many studies have been devoted to the toxic effect of the substances which we have studied on rats and some other vertebrates.

The toxicity of food colourings for rats (Spargue Dawley) has been studied by El-Wahab and Moram (2013). The experiments used the following colourings Brilliant Blue (124 mg/kg diet), Carmoisine (70 $\mathrm{mg} / \mathrm{kg})$, Tartrazine $(75 \mathrm{mg} / \mathrm{kg})$, and also all these colourings in combination with vanilin, propylene glycol and trans-Anethole. All colourings were observed to cause significant decrease in the body weight, concentration of hemoglobin and the number of erythrocytes. Also, a significant decrease was observed in the content of glutathiline, glutathione-S-transferase and superoxide dismutase in the blood and liver compared to the control. On the other hand, all groups were observed to have a significant increase in activity of serum alanine aminotransferase, aspartate aminotransferase, alkaline phosphatase activity, concentration of bilirubin, urea, creatinine, total protein and albumin compared to the control. A similar effect on the main biochemical markers was observed by Amin et al. (2010) in their study of the impact of Tartrazine and Carmoisine. Reyes et al. (1996) studied the effect of colourings including Ponceau, Allura Red, Sunset Yellow, Tartrazine, Brilliant Blue and others on breathing in mitochondria. All tested colourings inhibited mitochondrial breathing. This inhibition significantly varied for mitochondrial protein: from $100 \%$ to $16 \%$ for Tartazine at the concentration of $0.1 \mathrm{mg}$.

The toxicity of the colouring Sunset Yellow was studied by Gaunt et al. (1974). The colouring in the dose of $1-6 \%$ over 80 weeks caused no negative effect on the rats' survival, growth rate and weight of organs. Doses up to $10 \mathrm{~g} / \mathrm{kg}$ for rats and $6 \mathrm{~g} / \mathrm{kg}$ for mice were received with no side effects (Gaunt et al., 1967). The colouring is not a carcinogen and does not cause a long term toxic effect. Hashem et al. (2010) studied the impact of peroral administration over 4 weeks of Sunset Yellow in doses of 47.3 and $157.5 \mathrm{mg} / \mathrm{kg}$ of body weight on rats. The colouring did not cause increase in the body weight and weight of spleen, nevertheless the mass of thymus and content of monocytes significantly decreased. Synthetic colourings used in doses 10 times higher than the daily intake inhibit the cell response, but not the humoral immune response. According to Gaunt (1969), feeding pigs with food containing Sunset Yellow in concentrations of 250,500 and $1000 \mathrm{mg} / \mathrm{kg}$ over 98 days caused no change in increase in the body weight, hematological and other indicators in comparison with the control.

Saxena and Sharma (2014) studied the toxicity of Sunset Yellow and Tartrazine on Swiss Albino Rats Rattus norvegicus (Berkenhout, 1769). The concentration of this substance equaled 25,50 and $75 \mathrm{mg} / \mathrm{kg}$ of body weight; the experiment lasted 30 days. No death among the rats was observed. The colourings caused increase in the body weight in all doses. Decrease in total protein and albumin, increase in the level of alkaline phosphatase and bilirubin were observed in all groups compared to the control.

Tartrazine is a yellow colouring, widely used in food products, medications and cosmetics. Acceptable daily intake (ADI) for humans is $0-7.5 \mathrm{mg} / \mathrm{kg}$ of body weight. Himri et al. (2013) studied the toxicity of Tartazine and its main metabolite, sulfanilic acid, for $\mathrm{Cae}$ norhabditis elegans (Maupas, 1900) nematodes and Artemia salina (Linnaeus, 1758) larvae. Among C. elegans nematodes, concentrations of Tartrazine $3 \mathrm{mM}$ and sulfanilic acid $1 \mathrm{mM}$ caused disorders in the cell cycle, without causing death. A. salina were affected by Tartazine and sulfanilic acid in concentrations $1,2.5,5,7.5,10,25$, $50,75,100 \mu \mathrm{g} / \mathrm{ml}$ for 48 hours. Tartrazine showed no toxicity, and sulfanilic acid had low toxicity $\left(\mathrm{LC}_{50}=82.3 \mu \mathrm{g} / \mathrm{ml}\right)$. Paterson and Butler (1982) demonstrated that the effect of Tartazine in concentrations of $5-20 \mu \mathrm{g} / \mathrm{ml}$ induces chromosomal aberrations in the cells of Muntiacus muntjak (Zimmermann, 1780) fibroblasts. Carcinogenicity of Tartazine was studied by Maekawa et al. (1987) on $\mathrm{F}_{344}$ rats. Tartazine concentrations of $0.1 \%$ and $2.0 \%$ in potable water over 2 years caused no toxic damages, the colouring was not found to be a carcinogen. Davis et al. (1964) studied the chronic toxicity of Tartazine on rats and dogs. The experiments used Osborne-Mendel rats, which received diet containing Tartazine in $0,0.5,1.0,2.0$ and $5 \%$ for
2 years. Insignificant effects on growth were observed, but no effects on survival, hematology and body weight. The dogs received a diet containing Tartazine in $0.1 \%$ and $2 \%$ for 2 years. There were no symptoms of toxicity or hematologic anomalies observed. Gao et al. (2011) mentions the toxic effect of Tartazine on the memory and learning functions of rats and mice. A study of the neurotoxic impact of Tartazine was conducted by Mohamed et al. (2015). The rats were given Tartazine perorally in concentration of $500 \mathrm{mg} / \mathrm{kg}$ of body weight for 30 days. The analysis found significant decrease in concentrations of brain neurotransmitters, serious deficiency in the level of antioxidant biomarkers (superoxide dismutase, catalase and recovered glutathione), notable increase in the levels of malondialdehyde and numerous apoptotic cells in the cerebral cortex in comparison to other groups.

Mason et al. (1974) studied the toxicity of Carmoisine administered to mice in $0.01,0.05,0.25$ and $1.25 \%$ concentrations during 80 weeks. They observed no changes in death rate, no increase in the body weight and mass of the organs. At $1.25 \%$ concentration, a light anemia was observed. Carcinogenic potential of Carmoisine is absent at $1.25 \%$ concentration. Studying metabolism of Carmoisine in rats, mice and guinea pigs, Phillips et al. (1987) found that after administration of one peroral dose of $0.5 \mathrm{or} 50 \mathrm{mg} / \mathrm{kg}$ of body weight, practically the entire dose is removed through the feces during 72 hours.

Drake et al. (1978) studied the toxicity of the colouring Chocolate Brown HT in $0,0.01,0.1$ and $0.5 \%$ concentrations on mice for 80 weeks. Insignificant decrease in the body mass and heart of the males was observed at the $0.5 \%$ concentration. Carcinogenic effect at doses of up to $700 \mathrm{mg} / \mathrm{kg}$. day was not observed. In a similar study, Chambers et al. (1966) gave rats Chocolate Brown HT in 0, 0.02, $0.06,0.2,0.6,1.0$ and $2.0 \%$ concentrations for 90 days. Almost no side effects were observed, and the gain in body weight did not change, although, an insignificantly reduced growth rate among males was observed at $1 \%$ and $2 \%$ concentrations. The analysis found decrease in the content of hemoglobin, erythrocytes and hematocrit.

The toxicity of the colouring Ponceau was studied by Hansen et al. (1963) and Davis et al. (1966). They used 0.5, 1.0, 2.0 and 5.0\% concentrations. Over 2 weeks, these concentrations caused a high death rate of rats, reduced their growth rate, increased the mass of the liver and kidneys, and caused the formation of malignant and benign tumours. Loss of weight and high death rate was observed among dogs at $1 \%$ and $2 \%$ concentrations. A study of the acute toxicity of Ponceau was conducted on mice and rats by Gaunt et al. (1967). Similar studies were conducted by Brantom et al. (1987): $\mathrm{LD}_{50}$ was higher than $8 \mathrm{~g} / \mathrm{kg}$ orally in both species. Feeding rats with $0.0,0.5$, 1.0 and $2.0 \%$ concentrations of the colouring for 90 days caused no negative effects. At $2 \%$ concentration of Ponceau, the females were observed to have an insignificant decrease in the number of erythrocytes, and also increased activity of transaminases in the blood serum. The level of absence of the effect for rats is $500 \mathrm{mg} / \mathrm{kg}$ a day. Meyer and Hansen (1975) conducted a study of embryotoxicity of Ponceau for Wistar rats. The colouring was given using a stomach pump from 1 to 20th period of pregnancy in doses of $0,1000,2000$ and $4000 \mathrm{mg} / \mathrm{kg}$ a day. The analysis found no negative effects on the fetus.

Borzelleca et al. (1989) studied the toxicity of the colouring Allura Red for Sprague-Dawley rats. The colouring was administered in $0.0,0.37,1.39$ and $5.19 \%$ concentrations during the period of mating, feeding and lactation. No side effects related to the colouring were observed, except decrease in the body weight among females at high doses. The absence of side effects was observed at $2829 \mathrm{mg} / \mathrm{kg} \cdot$ day among males and $901 \mathrm{mg} / \mathrm{kg} \cdot$ day among females. A similar study was conducted by Vorhees et al. (1983). Physical and behavioural toxicity of the colouring was observed at concentrations of up to $10 \%$ of diet. A study of genotoxicity of Allura Red was conducted on mice by Honma (2015). At maximum accepted doses, genotoxic or mutagenic effects were not observed.

Hooson et al. (1975) conducted an 80 week study on the toxicity of Indigo Carmine in 0.2, 0.4, 0.8 and 1.6\% concentrations on mice. No effect on the death rate, gain in body weight, mass of organs and results of histopathological examination was found. An insignificant 
anemia was observed at $0.8 \%$ and $1.6 \%$ concentrations. This content of Indigo Carmine does not cause carcinogenic effect. Studying active transport of insects, Maddrell et al. (1974) determined that Indigo Carmine concentration is subject to passive penetrability of malpighian tubule walls. The speed of transfer of the colouring in insects is related to speed of liquid withdrawal.

The toxicity of the colouring Brilliant Blue was studied by Mannell et al. (1962). The rats were fed with the colouring in concentrations of $0.03,0.30$ and $3.00 \%$ of the diet for 75 weeks. The negative effect of the substance on growth was not observed.

The toxicity of saccharin was studied on rats by Munro et al. (1975). The diet contained sodium saccharin in concentrations of 0 , $90,270,810$ and $2430 \mathrm{mg} / \mathrm{kg} \cdot$ day of saccharin. Bladder tumours were found at doses of 90 and $810 \mathrm{mg} / \mathrm{kg}$. Decrease in the body weight and in life expectancy was observed among male rats. Taylor et al. (1980) studied chronic toxicity of sodium saccharin for rats. They used a diet with concentrations of $0,0.01,0.1,1.0,5.0$ and $7.5 \%$. Effects on hematological indicators, organ mass and survival were not observed. Increase in the frequency of the bladder hyperplasia was observed among male rats, which received $7.5 \%$ of sodium saccharin. Fitzhugh et al. (1951) provide data on insignificant effects of toxicity of saccharin for rats at a dose of $5 \%$.

Studying the toxicity of sweeteners for Mesocricetus auratus (Waterhouse, 1839) hamsters, Althoff et al. (1975) found that chronic administration of saccharin and sodium and calcium cyclomates caused no tumours even at maximum doses. Luini et al. (1981) report that rats, which received saccharin in 1.0, 2.5 and $5.0 \%$ concentrations for 54 days, were observed to have inhibition of formation of primary humoral antibodies. Zhang et al. (2017) report high indicators of death rate of Solenopsis invicta (Buren, 1972) ants under the impact of saccharin and state that it could be used as a low cost insecticide.

The toxicity of sodium cyclamate was studied on mice by Brantom et al. (1973). The substance was used in concentrations of $0.7,1.75,3.5$ and $7.0 \%$. A decrease in gain of body weight and mild anemia were observed. Effects related to the death rate, mass of organs and histological characteristics were absent. At a sodium cyclamate content of $7 \%$, no carcinogenic effect was observed. Ershoff (1972) studied the toxicity of natrium cyclamate for rats using concentrations of 2.5, 5.0 and $10.0 \%$ of the diet. He observed decrease in the mass, reduced growth rate, random alopecia and diarrhea. The concentration of $10 \%$ was lethal. The effects were manifested three days after the feeding. Friedman et al. (1972) studied the toxic effect of sodium cyclamates in $0.4-10.0 \%$ concentrations on rats during 101 weeks. They observed decrease in the survival rate, disorders of kidneys (nephrocalcinosis and polyposis) and bladder (hyperplasia).

The toxicity of the mixture "cyclamate + saccharin" for rats was studied by Oser et al. (1975). The study used the mixture in concentrations of 500, 1120 and $2500 \mathrm{mg} / \mathrm{kg}$ of body weight. The only result of the study was carcinomas in the bladders of the rats which received the maximum dose. Roe et al. (1970) report absence of observed toxic effects among mice which were fed with sodium cyclamate in 5\% concentration during 18 months. Taylor et al. (1968) studied the toxicity of sodium cyclamate and saccharin for mice, rats and dogs. Administration of $2 \%$ of cyclamate or mixture of cyclamate and saccharin (or intragastrically $1 \mathrm{~g} / \mathrm{kg} \bullet$ day) caused no effects on the rats. Intragastic administration of cyclamate $(4 \mathrm{~g} / \mathrm{kg} \cdot \mathrm{day})$ had no effects on the dogs. Decrease in food consumption at high levels was observed among some of the rats. Adding up to $3 \%$ sodium cyclamate to the diet of rats or $0.5 \mathrm{~g} / \mathrm{kg}$-day to the diet of dogs during 11 months was observed to have no negative effects.

The toxicity of sodium glutamate was studied by Mushahwar and Koeppe (1971). Intragastic injection of $4 \mathrm{mg} / \mathrm{g}$ to baby rats caused increase in glutamine in the brain. The toxicity manifested in spasms. Farombi and Onyema (2006) reported an increase in the formation of malonic aldehyde in the liver, kidneys and brain of rats. Eweka and Om'Iniabohs (2008) studied the impact of sodium glutamate on rats' kidneys. The animals received 3 and $6 \mathrm{~g}$ of sodium glutamate for 14 days. A negative effect was found, disorders in the cell structure and cell necrosis of the kidneys.
According to Olney (1969), hypodermic injection of sodium glutamate to new born mice caused brain necrosis. Mature individuals were observed to have retarded skeletal development, obesity, infertility, pathologies of the organs of the endocrine system. Malik and Ahluwalia (1994) studied the toxicity of sodium glutamate for concentrations 2,4 and $8 \mathrm{mg} / \mathrm{kg}$ of body weight, which was injected subdermally to mice during 6 days: carbohydrate metabolism tends to lipogenesis and results in hyperlipidemia. Injection of 4 and $8 \mathrm{mg} / \mathrm{g}$ of body weight significantly increased the activity of glutathione reductase, glutathione-S-transferase and glutathione peroxydase. Concentration of sodium glutamate above $4 \mathrm{mg} / \mathrm{g}$ of body weight causes oxidative stress and maintains the level of glutathione. This was achieved by increase in the activity of its metabolizing enzymes.

Pszczolkowski and Brown $(2002,2004)$ studied the impact of sodium glutamate on Cydia pomonella (Linnaeus, 1758) larvae which fed on the leaves of apple-trees. Addition of $25 \mathrm{ppm}$ of sodium glutamate increased the food consumption up to $20-30 \%$. Leaves with sodium glutamate $(0.05$ and $0.10 \mathrm{mg} / \mathrm{ml})$ increased the consumption of leaves up to $60 \%$ among the first age larvae. The effect of MSG also speeded up the moulting to the second age (Pszczolkowski et al., 2002). MSG is a feeding stimulator and intensifies the toxic properties of spinosad, which is a good regulator of pest insect populations.

The toxicity of benzoic acid was studied by Nair (2001). Benzoic acid can cause pathologies in the development of hamsters. Nevertheless, the studies on rats and mice found no negative effects on reproductive function, development, and no genotoxicity and carcinogenicity. Studying the acaricidal activity of benzoic acid in the cortex of roots of Paeonia suffruticosa (Andrews, 1804) against Tyrophagus putrescentiae (Schrank, 1781) acari, Tak et al. (2006) determined that it equals $4,80 \mu \mathrm{g} / \mathrm{sm}^{2}$.

A study on the toxicity of sodium benzoate for Danio rerio (Hamilton, 1822) was conducted by Tsay et al. (2007): LD $_{50}$ equaled $1450 \mathrm{ppm}$. These fishes were observed to have manifestations of neurotoxicity and nephrotoxicity. O'Connor et al. (1987) reported that sodium benzoate inhibits the synthesis of urea, which increases the death rate.

The toxicity of $\alpha$-olefin sulphonate for rats was studied by Hunter and Benson (1976). The animals were given the substance in 1000, 2500 and 5000 ppm concentrations for 2 years. No negative effects or decrease in survival rate were observed. Decrease in weight gain and in food consumption was observed in the group, which was given $5000 \mathrm{ppm}$. According to Nair (1998) peroral value of $\mathrm{LD}_{50}$ for Sodium Alpha-Olefin Sulfonates equaled 1.3-2.4 g/kg for rats and $2.5-4.3 \mathrm{~g} / \mathrm{kg}$ for mice. No effects were observed among mice at concentrations below $0.5-1.0 \mathrm{~g} / \mathrm{kg}$. Fetal anomalies were observed only at the doses toxic to the mother. Fitzhug and Nelson (1948) reported on the toxicity of sodium dodecyl sulfate. Peroral administration of Sodium dodecyl sulfate for two years caused no toxic effect at $1 \%$ dose. Sodium dodecyl sulfate in $4 \%$ concentration caused reduced growth rate.

Betaine is not toxic and is a typical component of intermediary metabolism. It is used in production of cosmetics and surfactants. Ramakrishna et al. (1998) showed that betaine is efficient in memory recovery (in case of memory loss caused by $\mathrm{Al}^{3+}$ ) through increase in the level of choline. Betaine can prevent formation of plaques in early stages of Alzheimer's disease. Betaine is a natural product of beet (Beta vulgaris Linnaeus, 1758), and in the process of production of sugar from beet this product can therefore be efficient in treating diseases related to dysfunctions of the cholinergic system, which cause memory loss. Alirezaei et al. (2011) report that betaine can prevent hyperhomocysteinemia and oxidative stress. The protective effect of betaine is related to its ability to strengthen the cells of the cerebellum membrane by intensification of antioxidative enzymes.

Despite numerous studies devoted to the toxic impact of food additives and surfactants on mammals, similar data on insects and other invertebrate organisms is absent. Our research demonstrates that for insects the effects of food additives can be different from those for animals and require further study. Also, T. molitor is a good model for studying the impact of compounds introduced into food. 


\section{Conclusion}

A significant change in the body weight of $T$. molitor larvae was caused by adding $350 \mathrm{mg} / \mathrm{kg}$ of sodium glutamate, cyclamate and sodium benzoate to their food. A tendency towards increase in body weight was observed with addition of Allura Red, saccharin, benzoic acid, betaine, emulsifying wax, AOS and SLES, and decrease in the body weight was observed with addition of the same concentrations of Tartrazine and Indigo Carmine.

Out of the 18 studied additives, 3 significantly stimulated increase in the body weight of third age T. molitor larvae, 3 manifested these capacities at the level of tendency (stimulated increase in the body weight on average by $43-58 \%$ over the 14-day experiment), and 2 caused decrease in the body weight of the larvae. Also, the 4 studied surfactants showed a tendency towards increasing the body weight of T. molitor. The study on the impact of food additives and surfactants on the organisms of insects is of great significance for protecting rare species of insects.

\section{References}

Alirezaei, M., Jelobar, G., Niknam, P., Ghayemi, Z., \& Nazifi, S. (2011). Betaine prevents ethanol-induced oxidative stress and reduces total homocysteine in the rat cerebellum. Journal of Physiology and Biochemistry, 67(4), 605-612.

Althoff, J., Cardesa, A., Pour, P., \& Shubik, P. (1975). A chronic study of artificial sweeteners in Syrian golden hamsters. Cancer Letters, 1, 21-24.

Amin, K. A., Hameidll, H. A., \& Elsttar, A. H. (2010). Effect of food azo dyes tartrazine and carmoisine on biochemical parameters related to renal, hepatic function and oxidative stress biomarkers in young male rats. Food and Chemical Toxicology, 48(10), 2994-2999.

Ashida, H., Hashimoto, T., Tsuji, S., Kanazawa, K., \& Danno, G. (2000). Synergistic effects of food colors on the toxicity of 3-amino-1,4dimethyl-5H-pyrido[4,3-b]indole (Trp-P-1) in primary cultured rat hepatocytes. Journal of Nutritional Science and Vitaminology, 46(3), 130-136.

Bobyliov, Y. P., Brygadyrenko, V. V., Bulakhov, V. L., Gaichenko, V. A., Gasso, V. Y., Didukh, Y. P., Ivashov, A. V., Kucheriavyi, V. P., Maliovanyi, M. S., Mytsyk, L. P., Pakhomov, O. Y., Tsaryk, I. V., \& Shabanov, D. A. (2014). Ekologija [Ecology]. Folio, Kharkiv. 672 p. (in Ukrainian).

Borzelleca, J. F., Olson, J. W., \& Reno, F. E. (1989). Lifetime toxicity/carcinogenicity study of FD \& C Red No. 40 (Allura Red) in Sprague-Dawley rats. Food and Chemical Toxicology, 27(11), 701-705.

Boyko, A. A., \& Brygadyrenko, V. V. (2017). Changes in the viability of Strongyloides ransomi larvae (Nematoda, Rhabditida) under the influence of synthetic flavourings. Regulatory Mechanisms in Biosystems, 8(1), 36-40.

Brantom, P. G., Gaunt, I. F., \& Grasso, P. (1973). Long-term toxicity of sodium cyclamate in mice. Food and Cosmetics Toxicology, 11(5), 735-746.

Brantom, P. G., Stevenson, B. I., \& Wright, M. G. (1987). Long-term toxicity study of Ponceau 4R in rats using animals exposed in utero. Food and Chemical Toxicology, 25(12), 955-962.

Brygadyrenko, V. V., \& Nazimov, S. S. (2014). Nutrition of Opatrum sabulosum (Coleoptera, Tenebrionidae) when fed on leaves of trees, shrubs and liana plants in the conditions of a laboratory experiment. Baltic Journal of Coleopterology, 14, 59-72.

Brygadyrenko, V. V., \& Nazimov, S. S. (2015). Trophic relations of Opatrum sabulosum (Coleoptera, Tenebrionidae) with leaves of cultivated and uncultivated species of herbaceous plants under laboratory conditions. ZooKeys, 481, 57-68.

Chambers, P. L., Hunter, C. G., \& Stevenson, D. E. (1966). Short-term study of Chocolate Brown HT in rats. Food and Cosmetics Toxicology, 4, 151-155.

Chen, X., Thompson, M. B., \& Dickman, C. R. (2004). Energy density and its seasonal variation in desert beetles. Journal of Arid Environments, 56(3), 559-567.

Davis, K. J., Fitzhugh, O. G., \& Nelson, A. A. (1964). Chronic rat and dog toxicity studies on tartrazine. Toxicology and Applied Pharmacology, 6(5), 621-626.

Davis, K. J., Nelson, A. A., Zwickey, R. E., Hansen, W. H., \& Fitzhugh, O. G. (1966). Chronic toxicity of Ponceau SX to rats, mice, and dogs. Toxicology and Applied Pharmacology, 8(2), 306-317.

Drake, J. J.-P., Butterworth, K. R., Gaunt, I. F., \& Hardy, J. (1978). Long-term toxicity studies of Chocolate Brown HT in mice. Toxicology, 10, 17-27.

El-Wahab, H. M. F., \& Moram, G. S. E.-D. (2013). Toxic effects of some synthetic food colorants and/or flavor additives on male rats. Toxicology and Industrial Health, 29(2), 224-232.
Ershoff, B. H. (1972). Comparative effects of a purified diet and stock ration on Sodium Cyclamate toxicity in rats. Experimental Biology and Medicine, 141(3), 857-862.

Eweka, A. O., \& Om'Iniabohs, F. A. E. (2011). Histological studies of the effects of monosodium glutamate on the kidney of adult Wistar rats. The Internet Journal of Health, 6(2), 37-43.

Farombi, E. O., \& Onyema, O. O. (2006). Monosodium glutamate-induced oxidative damage and genotoxicity in the rat: Modulatory role of vitamin $\mathrm{C}$, vitamin $\mathrm{E}$ and quercetin. Human and Experimental Toxicology, 25(5), 251-259.

Fitzhugh, O. G., \& Nelson, A. A. (1948). Chronic oral toxicities of surfaceactive agents. Journal of Pharmaceutical Sciences, 37(1), 29-32.

Fitzhugh, O. G., Nelson, A. A., \& Frawley, J. P. (1951). A comparison of the chronic toxicities of synthetic sweetening agents. Journal of Pharmaceutical Sciences, 40(11), 583-586.

Friedman, L., Richardson, H. L., Richardson, M. E., Lethco, E. J., Wallace, W. C., \& Sauro, F. M. (1972). Toxic response of rats to Cyclamates in chow and semisynthetic diets. Journal of the National Cancer Institute, 49(3), 751-764.

Gao, Y., Li, C., Shen, J., Yin, H., An, X., \& Jin, H. (2011). Effect of food Azo Dye Tartrazine on learning and memory functions in mice and rats, and the possible mechanisms involved. Journal of Food Science, 76(6), 125-129.

Gaunt, I. F. (1969). Short-term toxicity study on sunset Yellow FCF in the miniature pig. Food and Cosmetics Toxicology, 7, 9-16.

Gaunt, I. F., Farmer, M., Graso, S., \& Gandolli, S. D. (1967). Acute (rat and mouse) and short-term (rat) toxicity studies on Sunset Yellow FCF. Food and Cosmetics Toxicology, 5, 747-754.

Gaunt, I. F., Farmer, M., Grasso, P., \& Gandolli, S. D. (1967). Acute (mouse and rat) and short-term (rat) toxicity studies on Ponceau 4R. Food and Cosmetics Toxicology, 5, 187-194.

Gaunt, I. F., Mason, P. L., Grasso, P., \& Kiss, I. S. (1974). Long-term toxicity of Sunset Yellow FCF in mice. Food and Cosmetics Toxicology, 12(1), 1-9.

Hansen, W. H., Davis, K. J., Fitzhugh, O. G., \& Nelson, A. A. (1963). Chronic oral toxicity of Ponceau 3R. Toxicology and Applied Pharmacology, 5(1), 105-118.

Hashem, M. M., Atta, A. H., Arbid, M. S., Nada, S. A., \& Asaad, G. F. (2010). Immunological studies on Amaranth, Sunset Yellow and Curcumin as food colouring agents in albino rats. Food and Chemical Toxicology, 48(6), 1581-1586.

Himri, I., Guaadaoui, A. H., Souna, F., Bouakka, M., Melhaoui, A., Hakkou, A., \& Saalaoui, E. (2013). Toxicity testing of Tartrazine using the nematode Caenorhabditis elegans, brine shrimp larvae (Artemia salina) and KGN Granulosa Cell Line. Journal of Applied Pharmaceutical Science, 3(11), 51-58.

Honma, M. (2015). Evaluation of the in vivo genotoxicity of Allura Red AC (Food Red No. 40). Food and Chemical Toxicology, 84, 270-275.

Hooson, J., Gaunt, I. F., Kiss, I. D., Grasso, P., \& Butterworth, K. R. (1975). Long-term toxicity of indigo carmine in mice. Food and Cosmetics Toxicology, 13(2), 167-176.

Hunter, B., \& Benson, H. G. (1976). Long-term toxicity of the surfactant $\alpha$ olefin sulphonate (AOS) in the rat. Toxicology, 5(3), 359-370.

Kroes, R., \& Kozianowski, G. (2002). Threshold of toxicological concern in food safety assessment. Toxicology Letters, 127, 43-46.

Luini, W., Mantovani, A., \& Garattini, S. (1981). Effects of saccharin on primary humoral antibody production in rats. Toxicology Letters, 8, 1-6.

Maddrell, S. H. P., Gardiner, B. O. C., Pilcher, D. E. M., \& Reynolds, S. E. (1974). Active transport by insect malpighian tubules of Acidic Dyes and of Acylamides. Journal of Experimental Biology, 61, 357-377.

Maekawa, A., Matsuoka, C., Onodera, H., Tanigawa, H., Furuta, K., Kanno, J., Jang, J. J., \& Hayashi, Y. (1987). Lack of carcinogenicity of tartrazine (FD \& C Yellow No. 5) in the F344 rat. Food and Chemical Toxicology, 25(12), 891-896.

Malik, V. B. T., \& Ahluwalia, P. (1994). Studies on effect of monosodium glutamate (MSG) on various fractions of lipids and certain carbohydrate metabolic enzymes in liver and blood of adult male mice. Toxicology Letters, 74(1), 69-77.

Mannell, W. A., Grice, H. C., \& Allmark, M. G. (1962). Chronic toxicity studies on food colours: V. Observations on the toxicity of Brilliant Blue FCF, Guinea Green B and Benzyl Violet 4B in rats. Journal of Pharmacy and Pharmacology, 14(1), 378-384.

Mason, P. L., Gaunt, I. F., Butterworth, K. R., Hardy, J., Kiss, I. S., \& Grasso, P. (1974). Long-term toxicity studies of carmoisine in mice. Food and Cosmetics Toxicology, 12, 601-607.

Medvedev, H. S. (1968). Zhuki-chernotelki (Tenebrionidae) [Darkling beetles (Tenebrionidae)]. Nauka, Moskow - Leningrad. 419 p. (in Russian).

Meyer, O., \& Hansen, E. V. (1975). A study of the embryotoxicity of the food colour Ponceau 4R in rats. Toxicology, 5(2), 201-207. 
Mohamed, A. A.-R., Galal, A. A. A., \& Elewa, Y. H. A. (2015). Comparative protective effects of royal jelly and cod liver oil against neurotoxic impact of tartrazine on male rat pups brain. Acta Histochemica, 117(7), 649-658.

Moutinho, I. L. D., Bertges, L. C., \& Assis, R. V. C. (2007). Prolonged use of the food dye tartrazine and its effects on the gastric mucosa of Wistar rats. Brazilian Journal of Biology, 67(1), 141-145.

Munro, I. C., Moodie, C. A., Krewski, D., \& Grice, H. C. (1975). A carcinogenicity study of commercial saccharin in the rat. Toxicology and Applied Pharmacology, 32(3), 513-526.

Mushahwar, I. K., \& Koeppe, R. E. (1971). The toxicity of monosodium glutamate in young rats. Biochimica et Biophysica Acta - General Subjects, 244(2), 318-321.

Nair, B. (1998). Final report on the safety assessment of Sodium AlphaOlefin Sulfonates. International Journal of Toxicology, 17(1), 39-65.

Nair, B. (2001). Final report on the safety assessment of Benzyl Alcohol, Benzoic Acid, and Sodium Benzoate. International Journal of Toxicology, 20(3), 23-50.

Nazimov, S. S., \& Brygadyrenko, V. V. (2013). Does saprophagy play a significant role in nutrition of Opatrum sabulosum (Coleoptera, Tenebrionidae)? Visnyk of Dnipropetrovsk University. Biology, Ecology, 21(1), 43-50.

O'Connor, J. E., Costell, M., \& Grisolia, S. (1987). The potentiation of ammonia toxicity by sodium benzoate is prevented by L-carnitine. Biochemical and Biophysical Research Communications, 145(2), 817-824.

Olney, J. W. (1969). Brain lesions, obesity, and other disturbances in mice treated with Monosodium Glutamat. Science, 164, 719-721.

Oser, B. L., Carson, S., Cox, G. E., Vogin, E. E., \& Sternberg, S. (1975). Chronic toxicity study of cyclamate: Saccharin $(10: 1)$ in rats. Toxicology, 4(3), 385-386.

Patterson, R. M., \& Butler, J. S. (1982). Tartrazine-induced chromosomal aberrations in mammalian cells. Food and Chemical Toxicology, 20(4), 461-465.

Phillips, J. C., Bex, C., Walters, D. G., \& Gaunt, I. F. (1987). Metabolic disposition of ${ }^{14} \mathrm{C}$-labelled carmoisine in the rat, mouse and guinea-pig. Food and Chemical Toxicology, 25(12), 927-935.

Pszczolkowski, M. A, Matos, L. F., Zahand, A., \& Brown, J. J. (2002). Effect of monosodium glutamate on apple leaf consumption by codling moth larvae. Entomologia Experimentalis et Applicata, 103(1), 91-98.
Pszczolkowski, M. A., \& Brown, J. J. (2002). Prospects of monosodium glutamate use for enhancement of spinosad toxicity against codling moth neonates. Phytoparasitica, 30(3), 243-252.

Pszczolkowski, M. A., \& Brown, J. J. (2004). Enhancement of spinosad toxicity to Cydia pomonella neonates by Monosodium Glutamate receptor agonist. Phytoparasitica, 32, 342.

Ramakrishna, T., Vatsala, S., Shobi, V., Sreekumaran, E., Madhav, T. R., Ramesh, J., \& Easwaran, K. R. K. (1998). Betaine reverses toxic effects of aluminium: Implications in Alzheimer's disease (AD) and AD-like pathology. Current Science, 75(11), 1153-1156.

Reyes, F. G. R., Valim, M. F. C. F. A., \& Vercesi, A. E. (1996). Effect of organic synthetic food colours on mitochondrial respiration. Food Additives and Contaminants, 13(1), 5-11.

Roe, F. J. C., Levy, L. S., \& Carter, R. L. (1970). Feeding studies on sodium cyclamate, saccharin and sucrose for carcinogenic and tumour-promoting activity. Food and Cosmetics Toxicology, 8(2), 135-145.

Saxena, B., \& Sharma, S. (2014). Serological changes induced by Blend of Sunset Yellow, Metanil Yellow and Tartrazine in swiss albino rat, Rattus norvegicus. Toxicology International, 21(1), 65-68.

Tak, J.-H., Kim, H.-K., Lee, S.-H., \& Ahn, Y.-J. (2006). Acaricidal activities of paeonol and benzoic acid from Paeonia suffruticosa root bark and monoterpenoids against Tyrophagus putrescentiae (Acari: Acaridae). Pest Management Science, 62(2), 551-557.

Taylor, J. D., Richards, R. K., \& Wiegand, R. G. (1968). Toxicological studies with sodium cyclamate and saccharin. Food and Cosmetics Toxicology, 6(3), 313-327.

Taylor, J. M., Weinberger, M. A., \& Friedman, L. (1980). Chronic toxicity and carcinogenicity to the urinary bladder of sodium saccharin in the in utero-exposed rat. Toxicology and Applied Pharmacology, 54(1), 57-75.

Tsay, H. J., Wang, Y.-H., Chen, W.-L., Huang, M.-Y., \& Chen, Y.-H. (2007). Treatment with sodium benzoate leads to malformation of zebrafish larvae. Neurotoxicology and Teratology, 29(5), 562-569.

Vorhees, C. V., Butcher, R. E., Brunner, R. L., Wotten, V., \& Sobotka, T. J. (1983). Developmental toxicity and psychotoxicity of FD and C red dye no. 40 (Allura red AC) in rats. Toxicology, 28(3), 207-217.

Zhang, X., Chen, S., Li, Z., \& Xu, Y. (2017). Effect of sweeteners on the survival of Solenopsis invicta (Hymenoptera: Formicidae). Journal of Economic Entomology, 110(2), 593-597. 